\title{
Life Values Reflection in Idioms: Corpus Approach
}

\author{
Seda Yusupova \\ Grozny State Oil Technical University, Zhigulevskaya Street 11-60, 364059 Grozny, Russia \\ seda_linguistemail.ru
}

\begin{abstract}
The article deals with the analysis of semantics of the English, German, Russian and Chechen idioms representing such life values as trust, consent and success in globalization conditions. In different languages similarities are found in cognitive models of idioms' meanings, conceptualization of trust, consent, and success. The corpus approach has revealed distinctions in the actual meaning of quasi-equivalent idioms, the semantic properties and additional meanings which are not fixed in dictionaries.
\end{abstract}

Keywords: Idioms, Life values, Corpus approach.

\section{$1 \quad$ Introduction}

Life values take an important place in the value system in various cultures. The importance of life values is revealed at the level of a certain, specific person, and also in the context of society, group of people, culture, the country. The hierarchy of life values has a great influence on the psychological state and development of the personality, society.

\subsection{Hypothesis}

In the most general sense life values are universal for different cultures, but nevertheless there may be the peculiarities characteristic for this or that community, in languages both similarities, and non-trivial distinctions are found/evident.

The aim of this article consists in studying the semantics of the English, German, Russian and Chechen idioms representing life values: trust, consent and success. Cognitive and semantic analysis of idioms will allow to reveal cognitive models of meaning, similarities and distinctions in differently structured languages. Corpus approach will reflect the frequency and contexts of use of idioms, semantic and syntactic properties shown in real contexts; preferential spheres of use, stability or tendency to violation of phraseological integrity; influence of the inner form on actual meaning [2], ability of the compared idioms to appear as equivalents in translation - equivalence at the level of language and speech.

Under the influence of technical progress in the modern world there is such phenomenon as globalization, integration and convergence of different cultures and the people. Development of the international economy, distribution of democratic values 
and institutes, migration turn out to be consequence of globalization. In all these processes coincidence of life values as a factor of integration, consolidation and unification, overcoming dissociation and disagreement is of great importance. Values of trust, consent and success are necessary for building relationships, successful communication, development, self-realization and adaptation. The study of the semantics of idioms will reveal the universal, cultural and specific in perception of these values that will promote a dialog of cultures, consent and peace.

\section{Methodology}

In the work a complex of methods and approaches has been used: cognitive, semantic, comparative, corpus analysis. The material of research includes the English, German, Russian and Chechen idioms collected from phraseological dictionaries of the English, German, Russian and Chechen languages and also contexts of use from The British National Corpus, the Corpus of the Institute of the German language (IDS) in Mannheim, and the National Corpus of Russian. On the example of these idioms it is possible to see the conceptualization of trust, consent and success in different languages. The non-equivalent idioms entering the same taxa have semantic and conceptual similarities, revealing the common cognitive models of meaning. Also such selection of idioms shows specifics of phraseological funds.

\section{Content}

\subsection{Analysis of the idioms describing trust value}

In cognitive linguistics the idioms are considered as cognitive structures, and their semantics, meaning and form as a result of mental transformations. Construction of cognitive models of meaning of idioms will allow to reveal various options of their functioning in speech, conceptual similarities and distinctions in different languages.

English. Pin your faith / hopes on sb/sth - "to put your trust in sb/sth; hope for sb/sth".

Trust - an attachment of belief, hopes to someone - making a connection, touching.

....... you really can't afford to pin your hopes on the rather uncertain prospects currently in the wind (BNC, 2009).

German. In German trust is described as a lack of legal confirmation.

Auf Treu und Glauben - "(without legal security), conscientiously, in good faith".

"Wir brauchen ein sicheres System und können künftig nicht mehr auf Treu und Glauben arbeiten". Eine Vertragskündigung schloss er nicht aus, er bezeichnete sie aber als "eher theoretische" Möglichkeit (Rhein-Zeitung, 14.02.2004). (We need a sure employment contract and cannot work in good faith in future anymore. He did 
not exclude a termination of contract, he called it, however, "rather theoretical" possibility).

The context reflects the necessity of providing protection of the rights of workers.

Russian. Войти в доверие (lit. "to come into trust") - "to gain the trust". Trust as making good relationships.

Втираться в доверие (lit. "to creep into trust") - "to get trust by all means, to try to obtain someone's favor". To get trust in the unusual way that is expressed in the verb, with effort, using some means. In the context has a negative connotation, accentuating insincerity of motives.

Он удалял от себя людей порядочных и разумных, к нему стали втираться в доверие карьеристы, интриганы, проходимщь (Борис Ефимов. Десять десятилетий (2000)). (He deleted from himself decent and reasonable people, careerists, intriguers, rogues began to ingratiate with him).

Chechen. In the Chechen language the attempt to receive trust to what you are telling, convincing of or the information you report is expressed in the idioms denoting oath assurance, the appeal to oaths.

Лаьттан буха гІойла со (lit. "may I go under the earth") - "readiness to die or go to another world as the proof of sincerity, truthfulness of words". Receiving trust readiness to sacrifice life.

Делан возаллора (lit. "by greatness of God") - "expression of assurance, confirmation, etc. in something". The address to God, for the proof of sincerity and honesty. Trust - faith in God, feeling of reliability and trust at the mention of God.

Налха хьакха (lit. "to butter") - "with flattery, cunning obtain a favor, trust from someone". Gaining trust using extraordinary tools for making the relations.

Trust - belief in sincerity and truthfulness, overcoming distance, gaining the trust, using different means.

\subsection{Analysis of the idioms describing consent value}

English. Speak/ talk the same/ a different language - "to share / not share ideas, experiences, opinions, etc., that make real communication or understanding possible".

As leaders, we share the same values, and as you said, on so many issues we see the world in the same way. And most of the time, we speak the same language (BNC, 2015).

A gentleman's agreement (also gentlemen's agreement) - "an agreement, a contract, etc. in which nothing is written down because both people trust each other not to break it". Image of the gentleman as a guarantee of honesty, responsibility, reliability.

For the most part, opponents are cooperative, but they are under no requirement to exchange films with a nonconference team. It is simply a gentleman's agreement when they do (BNC, 2013). 
Build bridges (between $A$ and $B$ ) - "if you build bridges between people who disagree on sth or who do not like each other, you try to find ways to improve the relationship between them". Consent, friendly relations, peace - construction of bridges connection, communication, contact.

The goal of the initiative, which was formed from a 2005 grant, is to build bridges with neighborhoods, law enforcement and faith-based groups to create meaningful and sustainable conversations (BNC, 2015).

Meet $s b$ halfway - "to reach an agreement with sb by giving them part of what they want". Consent - meeting someone on the half way - making contact, though not full, to agree partly. In contexts the meaning is to achieve an agreement.

I think we need to compromise, though. If I'm going to see things the way I see them, then we just need to meet halfway (BNC, 2001).

Pour oil on troubled waters - "to try to settle a disagreement or dispute; take action which will calm a tense or dangerous situation". Reaching an agreement - pouring out oil on uneasy water - calming down.

My own temperament is one that is forever seeking to pour oil on troubled waters (BNC, 2000).

Thus, in idioms the spatial metaphor is mentioned. The consent is associated with closeness, disagreement with distance, overcoming disagreement is a construction and mitigation. National and cultural specificity is also expressed in the second idiom, the gentleman means the noble person from whom the high level of behavior is expected.

German. Dieselbe /die gleiche Sprache sprechen (lit. "to speak the same language") - "to have the same opinions, the same level and therefore get on well". In the contexts also dieselbe Sprache reden, die gleiche Sprache haben, lernen.

a. Sie kommen aus diversen Ländern und Kulturen, lernen jedoch dieselbe Sprache: Insgesamt 15 Migrationskinder aus Thusis besuchen seit November den Deutschkurs des Pilotprojekts «sprachliche Frühförderung» (Die Südostschweiz, 18.03.2011). (They come from various countries and cultures, nevertheless, learn the same language: A total of 15 migration children from Thusis visit since November the German course of the pilot project «early language support»).

b. Das Theater war immer eine Basis, damit sich Menschen besser verstehen können. Es ist eine Kunst ohne irgendwelche Grenzen. Egal, ob man dieselbe Sprache spricht: Man kann Theater miteinander spielen (Die Presse, 08.06.2011). (The theatre has always been a base, so that people can better understand each other. It is an art without any borders. It doesn't matter whether one speaks the same language or not: you can play theatre with each other).

Eine Brücke schlagen - "to make a connection". In the contexts also such variants as: bauen, spannen, stellen. The structure of the idiom can be violated as in the following context.

Doch meine Frau spricht Deutsch und ich Japanisch, das erleichtert vieles. Ausserdem liebe ich es, täglich eine Brücke zwischen Kulturen zu schlagen (St. Galler Tagblatt, 29.08.2014). (However, my wife speaks German and I Japanese, this makes easier a lot. Moreover, I love to build daily a bridge between cultures). The 
importance of language in the process of integration, and also the knowledge of culture is emphasized. Art acts as a uniting factor.

Russian. Находить/найти общий язык (lit. "to find a common language") - "to try to obtain, reach full mutual understanding".

а. Я мог разговаривать и находить общий язык не только с людьми, но с камнем, речкой, звездами, с любой травинкой (Ирина Краева. Тим и Дан, или Тайна «Разбитой коленки»: сказочная повесть (2007)). (I could talk and find a common language not only with people, but with a stone, river, stars, with any grass).

b. Мне бы именно хотелось научить его находить общий язык с теми, $c$ кем интересы не совпадают (коллективный. Форум: Компьютерные игры (2012)). (I would like to teach him to find a common language with those with whom interests do not coincide).

In many contexts it is said about talent, ability, importance to find a common language, a positive quality in economy, on service (political), at work.

Chechen. Kybŭza mIe куьг moxa (lit. "to strike a hand with a hand") - "to agree, make a decision with someone about something". Agreement, consent - close contact - overcoming distance.

Цхьа мотт каро (lit. "to find one language") - "to try to obtain, reach full mutual understanding, consent". Consent - common language - existence of means to report information, instrument of impact on the interlocutor, creation of communication, contact.

\subsection{Analysis of the idioms describing success value}

English. Have come a long way - "have made a lot of progress and achieved a lot". The meaning in contexts is "a progress, not material, not connected with wealth, public, scientific progress, improvement and coming to an understanding. Success is presented as an experience and achievement as a result of experience and a long way. Success - a way - to pass a long way from a starting point. Also be crowned with success for making progress.

a. Do you think America is changing for the better? It's clear we have come a long way (BNC, 2014).

b. But, in terms of women in politics, there certainly are more women serving in the Congress, 20 percent of the Congress. It's not parity, but women have come a long way (BNC, 2014).

German. von Erfolg gekrönt wurden/sein (lit. "to be crowned by success") - "to lead to success, finish successfully".

Die Arbeiten des Studios waren über Jahrzehnte von Erfolg gekrönt, man hatte unzählige Weltstars unter Vertrag (siehe Infobox) (Luxemburger Tageblatt, 
06.11.2010). (The works of the studio were crowned for decades by success, there were countless world stars under contract (see info box)).

Also weit gekommen (lit. "gone far"). "Ich muss ihnen eine Million Blumensträuße schicken - ohne die Kontroversen wäre ich nie so weit gekommen" (Rhein-Zeitung, 15.12.2016). ("I must send them one million bouquets - without controversies I would never have come so far").

Russian. Пробивать (прокладывать, пролагать себе дорогу, путь) / пробить себе дорогу (lit. "to punch (to lay the road, way) / to carve one's way") - "to obtain a certain status, success in life, in any field". In contexts the inner form influences the actual meaning, close to direct, literal, to achieve something, to receive something with effort". Success - a road, way - passing a way, an opportunity to move forward.

В свою очередь, рост объемов добычи заставляет российские компании активнее "работать локтями" и пробивать себе дорогу на новые рынки сбыта (Василий Богачев. Врата в поднебесную. Достижение экономических договоренностей открывает политические перспективы (2001) // «Известия», 2001.07.23). (In turn, growth of volumes of production makes the Russian companies more actively "work with elbows" and carve their way to new sales markets).

Mbl должны дать возможность прокладывать дорогу в неизведанное тем, кто способен добиваться выполнения общей задачи полета талантом, ответственностью, преодолением трудностей и своих слабостей ради согласия в экипаже и в интересах процветания жизни на Земле (Роль человека в космическом полете (2004) // «Жизнь национальностей», 2004.03.17). (We must give the chance to carve the way into unknown to those who are capable to ensure performing the general task of flight by talent, responsibility, overcoming difficulties and weaknesses for the sake of a consent in crew and for the benefit of prosperity of life on Earth).

Далеко пойти [уйти] (lit. "to go far") - "to achieve big success in life, big results in sth".

Можете далеко пойти. Вверх по служебной лестнице, разумеется (Сергей Романов. Парламент (2000). (You can go far. Up the career ladder, certainly).

Chechen. Некъ баккха (lit. "to open the way") - "to obtain the status, success in life, in some field". Also has the meaning "open the new horizons, roads", "acquire the right for something". Success - moving forward, far from a starting point on a horizontal scale.

Гена ваха (lit. "to go far") - "to achieve great success in life, big results in something (sometimes about someone not having respect)".

\section{Conclusion}

Corpus approach has shown that in contexts the idioms reveal new meanings, shades of meaning, significant for finding functional correspondences in different languages, 
for the correct use of idioms in speech. At the same time, the analysis of semantics of idioms in different languages and cultures has shown conceptual similarities and distinctions. In all languages the trust is based on belief, lack of proofs and official written legal confirmation. Consent and reaching an agreement as finding a common language, tool for information report, explanation of the position. An important conceptual similarity is the spatial metaphor "trust and consent - being close", "mistrust, disagreement - being far". Success is associated with a road and moving forward on a horizontal scale. Distinctions are caused by national and cultural specifics. The trust, consent and success are significant values in societies that is expressed in the issues touched upon in modern contexts, migration, successful communication in the process of integration and coexistence.

\section{References}

1. Baysultanov, D., Baysultanov, D. Chechensko-Russkiy phraseologicheskiy slovar. Grozny: Kniga, 320s. (1992).

2. Baranov, A.N., Dobrovolsky, D. O. Aspekti teorii frazeologii. M.: Znak, 656s. (2008).

3. Frazeologicheskiy slovar russkogo yazika / Pod red. i s posl. A.I. Molotkova. - 7-e izd., ispr. M.: AST: Astrel, 524p. (2006).

4. Duden Redewendungen. Wörterbuch der deutschen Idiomatik 3., überbearbeitete und aktualisierte Auflage. (Duden Band 11). Mannheim etc.: Dudenverlag (2008).

5. Oxford idioms Dictionary for learners of English. Oxford University Press. 470p. (2006).

6. http://www.ids-mannheim.de/kl/.../korpora/

7. http://www.ruscorpora.ru/

8. http://corpus.byu.edu/bnc/ 